\title{
Metaphors we live by
}

José Carlos Escobar Hernández

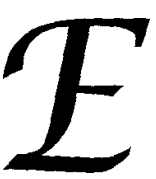

n este libro se presenta evidencia lingüística suficiente para demostrar que la metáfora desempeña un papel mucho más importante del que hasta ahora le había concedido la filosofía occidental relacionada con el estudio del significado. Los autores demuestran que es erróneo seguir pensando que la metáfora es un recurso de la imaginación poética o del preciosismo retórico, seguir creyendo que la metáfora es un asunto relacionado con el lenguaje extraordinario y que nada tiene que ver con el lenguaje ordinario. Pero, lo que más les interesa es demostrar que la idea de que la metáfora es una característica relacionada sólo con el lenguaje también es un error, pues ello implica verla nada más como un asunto lingüístico y no como un asunto que se relaciona con la acción y el pensamiento.

Como una continuación de trabajos realizados anteriormente a ellos por Edward Sapir, Benjamin Lee Whorf y otros, los autores demuestran que la metáfora está presente en el lenguaje y en el pensamiento cotidianos y analizan en esta obra la manera en que el idioma refleja el sistema conceptual de quienes lo hablan. Entre sus ejemplos podemos mencionar dos, que resultan particularmente interesantes para quienes nos dedicamos a la enseñanza de lenguas extranjeras.

Uno es el relacionado con la manera en que concebimos el fenómeno de la comunicación, dado que le atribuimos metafóricamente ciertas imágenes conceptuales, a saber: pensar que las ideas son cosas u objetos que pueden ser guardados en recipientes llamados palabras, las cuales podemos enviar o transmitir a través de un canal o medio (metáfora del conducto) que el receptor puede sacar de su envoltura. Los autores demuestran cómo funciona esta metáfora con evidencia lingüística, en una interacción como ésta:

- No fue nada fácil transmitirles nuestra idea, ¿verdad?

- No, pero al fin pudimos hacérselas llegar

$\mathrm{Y}$ en los casos en que decimos:

- Acuérdate que yo te di la idea

- Lo siento, pero no sabe pulir sus ideas

- Lo tengo en la punta de la lengua.

El otro ejemplo es el de la metáfora que establece que una discusión o argumentación es una guerra, por la manera en que hemos concebido este fenómeno y por la manera en que la llevamos a cabo, pues por un lado decimos:

- Atacó los puntos débiles de mi argumentación

- Te defendiste con muy buenos ejemplos

- Echó por tierra todas mis teorías

$Y$ por el otro efectivamente podemos ganar o perder, vemos como oponente a nuestro interlocutor, atacamos sus puntos de vista y defendemos el nuestro, nuestra posición. Este es sólo un ejemplo de la manera en que vivimos culturalmen te, pues esta manera de expresarnos estructura la manera en que llevamos a cabo nuestros intercambios de ideas y experiencias, nuestra comunicación. 


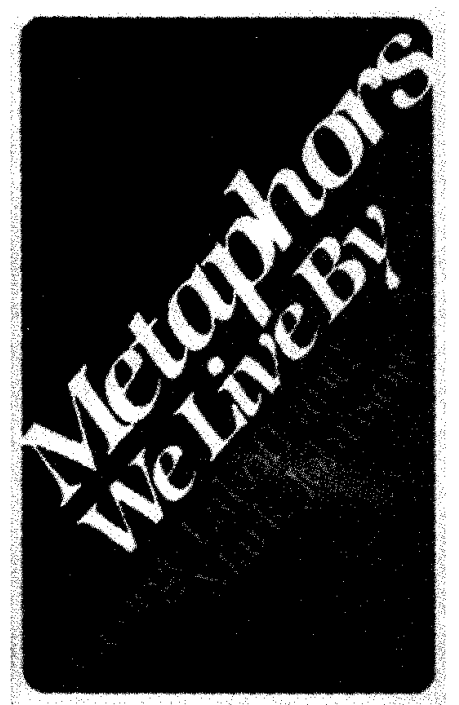

Lakoff George and Mark Johnson, Metaphors we live by, The University of Chicago Press Chicago and London, United States, 1980, pp241.

Así, tras la lectura de esta obra caemos inmediatamente en la cuenta de que una frase cotidiana como "iQué pesado está el tráfico!", la cual decimos todos los días mientras vamos a nuestro lugar de trabajo o bien de regreso a casa, produce una reacción en nosotros mismos y en quien nos escucha, incide en nuestro comportamiento y es prueba irrefutable de que no solemos expresarnos sin recurrir a la metáfora, pues usamos la palabra "peso" para dar la idea de que nos "abruma" el tráfico.

Entre otros, los autores abordan temas como:

1. La sistematicidad y coherencia cultural de los conceptos metafóricos

2. La manera en que una expresión suele resaltar ciertos detalles y ocultar otros que son parte de una misma idea o concepto

3.Distinguen entre las metáforas de orientación espacial (antropológica), y las metáforas ontológicas (con las que expresamos lo que son las cosas)

4.Y nos hablan de la manera en que funcionan la personificación y la metonimia, para finalizar con un análisis crítico de los mitos del pensamiento objetivo y del pensamiento subjetivo

5. Proponen el método de la "experiencia", donde se entrelazan la objetividad y la subjetividad como dos partes de un mismo todo.

Este libro ayuda a pensar de una manera novedosa sobre el lenguaje que empleamos todos los días; a considerar la metáfora desde una nueva perspectiva y a detectar su presencia en el habla cotidiana, cuyo uso afecta la manera en que vemos las cosas que percibimos y sobre las cuales pensamos y respecto de las cuales actuamos.

Los autores demuestran cómo la realidad misma se halla definida por la metáfora o los recursos metafóricos de un idioma, y la manera en que al variar de una cultura a otra las metáforas hacen variar las realidades que definen.

Esto ultimo es muy interesante pues tiene que ver con un concepto muy común que suele ser tomado a la ligera: nuestra visión del mundo, concepto fundamental entre los profesores de lenguas extranjeras, principales negociadores de sentido y significado dentro del aula, y quienes más conscientes deben de estar en todo o relacionado con el fenómeno metafórico del idioma que habaln cada uno de sus estudiantes y del propio.

*George Lakoff es profesor de lingüística en la Universidad de California, en Berkley.

Mark Johnson es profesor de filosofia en la Universidad de Oregon 